\title{
Year of the LGBTQ Candidate? LGBTQ State Legislative Candidates in the Trump Era*
}

\author{
Donald P. Haider-Markel, University of Kansas \\ Patrick Gauding, University of Kansas \\ Andrew Flores, American University \\ Daniel C. Lewis, Siena College \\ Patrick Miller, University of Kansas \\ Barry Tadlock, Ohio University \\ Jami K. Taylor, University of Toledo
}

\begin{abstract}
The Trump era has facilitated the emergence of a strong backlash against the successes of the LGBTQ movement. However, the politics of this era also motivated a record number of LGBTQ candidates to run for public office. We examine the electoral performance of these candidates in the 2018 election cycle relative to non-LGBTQ candidates employing state legislative election data from partisan election states in the updated State Legislative Election Returns (SLERs) database. We also conduct a brief case study of elections in Virginia, which led to the nation's first transgender state legislative representative taking office, to understand how a number of LGBTQ candidates overcame seemingly long electoral odds in 2017. Drawing on recent research on public attitudes toward LGBTQ rights, we expect to find that most LGBTQ candidates for state legislative seats rode on a Democratic wave and did not experience an electoral deficit for being LGBTQ. We will discuss the implications of our findings for potential LGBTQ candidates and political representation of the LGBTQ community in state politics.
\end{abstract}

Keywords: LGBTQ candidates, state legislative elections, electorate, partisanship

Words: about 3,000

*Paper prepared for presentation at the annual meeting of the American Political Science Association, Washington, DC, August 2019. This project is part of a 2018 election symposium for PS: Political Science \& Politics, organized by Carl Klarner. Much of the election data used in this project were compiled by Carl Klarner and will be made available through Harvard's Dataverse after an embargo. 
In 2017 transgender woman Danica Roem stunned political observers in Virginia by unseating a long-time anti-LGBTQ legislator from the Virginia House of Delegates. ${ }^{1}$ She was the first person elected to a state legislature as openly transgender. Delegate Roem's election seemed to mark a high point in LGBTQ representation, but as candidates emerged for the 2018 election cycle, it was clear that there was a greater potential for a rainbow wave, especially in local and state elections. In this brief essay we examine whether Delegate Roem's election was a momentary blip in LGBTQ representation or simply a foreshadowing of a wave that swept many non-traditional candidates into office during the 2018 elections. We focus on LGBTQ candidates in state legislative elections and examine whether or not sexual orientation and gender identity played a role in candidate electoral success.

Existing research on the role of sexual orientation in elections suggests that sexual orientation is at worst a non-issue in most elections (Magni and Reynolds 2018; Reynolds 2018), and perhaps even be a benefit to many candidates (Haider-Markel 2010). In part this appears to be due to the fact that gay and lesbian candidates have been strategic about when and where they run for office-often running after they have acquired considerable party and/or political experience and running in jurisdictions whose demographics would suggest less opposition to a gay candidate (Haider-Markel 2010). In addition, most gay candidates run as Democrats, thus avoiding the fact that the strongest opponents to gay candidates are unlikely to vote for any Democratic candidate (Haider-Markel 2010). We know less about potential opposition to bisexual candidates, but given that voters are likely to consider their sexual orientation about the same as the sexual orientation of gay candidates, we would expect the profile of opponents

\footnotetext{
${ }^{1}$ By LGBTQ we mean lesbian, gay, bisexual, transgender, and queer.
} 
to be similar.

The literature on transgender candidates is thin (but see Casey and Reynolds 2015), with much of it based on survey responses to hypothetical candidates, but does suggest that transgender candidates face greater opposition than do gay and lesbian candidates (HaiderMarkel et al. 2017; Jones et al. 2018; Taylor, Lewis, and Haider-Markel 2018). However, the profile of the voter more likely to support a transgender candidate is very similar to that of a voter likely to support a gay candidate-female, younger, college educated, less religious, and leaning Democratic and liberal (Haider-Markel et al. 2017).

\section{A Rainbow Wave?}

The advent of the Trump Administration mobilized many women and people from marginalized communities to more actively participate in politics, including attending protests and voting in elections. Indeed, Erica Chenoweth and Jeremy Pressman have tracked protests since the 2016 election and suggest that 2017 saw an exceptional number of protests, with perhaps over 4 million protesting for the Women's March in January (2017). ${ }^{2}$ In addition, during off-year state elections in places like Virginia, and special elections in state such as Alabama, voter participation, especially among women and people of color, was especially high. As the 2018 midterm election approached the number of non-traditional candidates running for office at every level of government broke previous records. In Congress alone a record women, people of color, and LGBTQ people were elected to serve, with women reaching 117 and LGBTQ

\footnotetext{
${ }^{2}$ For data on protests in the U.S. see the Crowd Counting Consortium, https://sites.google.com/view/crowdcountingconsortium/home
} 
members hitting 10, including Native American lesbian Sharice Davids (D-KS) (Zhou 2019). In total more than a record 150 LGBTQ candidates were elected to office in 2018 (Caron 2018). One election of interest occurred in 2017 during Virginia's state legislative elections and involved Danica Roem. Roem stood out because she was a transgender candidate. She became a reporter after graduating from College, which is how she became interested and involved in politics. In 2016 Roem was recruited to run for the legislature by the Virginia House Democratic Caucus (Darby 2018). She began a grassroots campaign in the $13^{\text {th }}$ district for the Virginia House of Delegates. In the Democratic primary Roem contended with three other candidates for the seat. She believed she had an edge that provided her with $43 \%$ of the vote because she focused on local issues and how she would address them (Darby 2018). Party support, in the form of the Caucus's encouragement to run, certainly also gave Roem a leg up over the other contenders for the nomination and her gender identity did not appear to hinder her electoral support. In the general election Roem faced 25-year incumbent Republican Bob Marshall. Marshall had declared himself Virginia's "chief homophobe" and had attempted to pass legislation restricting public bathroom use for transgender people (Olivo 2017b). Roem's approach in the general election followed the script of focusing on local issues, especially roads and traffic, which she argued were being ignored by Marshall and the legislature (Olivo 2017b).

Roem had early financial support from the Victory Fund (a PAC supporting LGBTQ candidates) and EMILY's List (a PAC supporting female candidates). But she also had small donations from Virginia and around the country, and her campaign fund swelled to almost $\$ 500,000$, dwarfing the funds raised by Marshall (Olivo 2017a).

Roem was an aggressive campaigner, spending nearly every day at meet-and-greet 
events, canvasing door-to-door, and always effectively using social media in the process (Olivo 2017a). Her opposition attempted to make her gender identity a campaign issue, launching an ad accusing Roem of lewd behavior and of "promoting transgender education in public school for children as young as 5 years old" (Sullivan 2017). Marshall also refused to debate Roem and consistently called her "he" (Sullivan 2017). Roem's campaign also insisted that voters in the district were receiving anti-transgender robo calls making false claims about Roem (Lavers 2017). However, Marshall's efforts appeared to fall flat with voters.

As it became clear election night that Roem had won, she spoke to her victory party: "To every person who's ever been singled out, who's ever been stigmatized, who's ever been the misfit, who's ever been the kid in the corner, who's ever needed someone to stand up for them when they didn't have a voice of their own....This one is for you." (Olivo 2017b).

During the 2018 election cycle there was a record wave of LGBTQ candidates running for local, state, and national office. Most election cycles since the late 1990s have witnessed an increase in the number of LGBTQ candidates (Haider-Markel and Gauding 2019), but even the Victory Fund was amazed by the record numbers (Stack 2018). During the primary season there were 18 transgender candidates for state legislative seats, but half of them made it to the general election. ${ }^{3}$ By the time of the general election in November, there were 180 LGBTQ candidates running for state legislative seats. Of these 70 (38\%) were incumbent legislators. Of these candidates it was split between men and women-lesbians and transgender women represented a greater proportion of candidates than they had in the past (Haider-Markel 2010).

\footnotetext{
${ }^{3}$ Data are from Logan Casey, https://www.loganscasey.com/transgender-candidates-2018. Accessed 22 May 18.
} 


\section{Research Design and Data}

Recall that central to our focus is whether state legislative candidate LGBTQ status influences the likelihood of being elected or percentage of the two-party vote received. As such, our unit of analysis is the state legislative (single-member) districts in each state holding legislative elections in 2018, and includes the 45 states with partisan elections. For our initial analysis we simply examine state and candidate characteristics in a multivariate model predicting the likelihood of a candidate winning (receiving more than $50 \%$ of the two-party vote). ${ }^{4}$

LGBTQ legislators were identified through public sources, including the Victory Fund, newspapers, candidate websites, and online news sources. Only candidates that self-identified as LGBTQ in these public sources were counted as LGBTQ. For the 5,485 races captured in our analysis, there were 180 LGBTQ candidates, or $3.3 \%$ of the candidates. For our preliminary analysis we are only focusing on whether the Democrat won the race since $98 \%$ of LGBTQ candidates ran as Democrats. We also include a dummy variable for whether or not the candidate was and incumbent on the basis that incumbents are reelected at very high rates (Hogan 2008). Likewise we include a lagged incumbency variable based on the notion that an open seat contest will be more competitive. We also control for candidate gender and whether the candidate held a seat in the other legislative chamber in the state. ${ }^{5}$

Our model also accounts for district characteristics, including average income, college education, African American population, Hispanic population, Protestant Fundamentalist

\footnotetext{
${ }^{4}$ This study was preregistered under "LGBT State Legislative Candidates in the Trump Era" at: https://osf.io/48a62/

${ }^{5}$ Candidate gender was coded based on the candidate's name by two teams involved in the symposium. Other chamber variable is coded as $1=$ Democratic candidate held office in the other state legislative chamber immediately before the election, $0=$ neither party...., $-1=$ Republican candidate.
} 
population, proportion of same-sex partner households, percent of the two-party vote for the

Democratic candidate in the last election, and a dummy variable for upper chamber district. ${ }^{6}$

We expect that the Protestant Fundamentalist population will decrease the likelihood that a

Democratic candidate will win the race, ${ }^{7}$ while the proportion of same-sex partner households

will be increase the likelihood that the Democratic candidate will win the race. ${ }^{8}$ We do not hold rigorous expectations for the other district characteristics measured.

\section{Preliminary Results}

In a bivariate logistic regression with a dichotomous variable coded one if the Democrat won the election and candidate LGBT status coded as one for a LGBT Democrat, zero for nonLGBT, and minus one for an LGBT Republican, the LGBT variable is positive and statistically significant below the .01 level. However, once we account for the remaining candidate and district characteristics candidate LGBT status has no discernable influence in the model (see Table 1). The model suggests that Democrat candidates were more likely to be successful where we would expect, in districts with more education, more urban, a larger LGBTQ population, and a more diverse population. The results also indicate that female candidates where no more likely to win the election than were male candidates.

\section{Final Thoughts and Conclusion}

\footnotetext{
${ }^{6}$ Unless otherwise noted all data are in percent or proportion and were collected from U.S. Census data by Carl Klarner and will be available under his name through Harvard's Dataverse.

${ }^{7}$ Calculated with data from Glennmary Research Center on Religion and population data from Klarner's Harvard's Dataverse; weighted as county proportion of state legislative district.

${ }^{8}$ Calculated with data from the U.S. Census and population data from Klarner's Harvard's Dataverse.
} 
The preliminary evidence suggests that 2017-18 election cycle did indeed represent a Rainbow Wave in American politics with more LGBTQ candidates elected to office than ever before. Ironically this wave appeared as anti-LGBT forces appeared to have more power in Washington and many states than they had during the previous 10 years. We examine this wave election in greater detail to determine if candidate LGBTQ status influenced electoral outcomes.

Our analysis of 2018 state legislative elections from most American states allows us to draw several important preliminary conclusions. First, in an election cycle where many nontraditional candidates threw their hats into the ring, LGBTQ candidates followed this wave and more ran for office in higher numbers, many successfully, than they had in past elections. This increase in candidates fits a continuing pattern of LGBT candidates running for office since the 1990s.

Second, candidate LGBTQ status did not influence election result outcomes, at least when a variety of district characteristics are accounted for. A positive relationship between candidate LGBTQ status and the election outcome disappeared once factors such as district education and diversity were accounted for. However, the evidence clearly does not support the notion that LGBTQ candidates face an electoral hurdle.

Third, the combination of results suggests that candidate LGBTQ status does not harm a candidate's electoral chances in large part because LGBTQ candidates are strategic in choosing how, where and when to run for the state legislature. On average LGBTQ candidates are running as Democrats in districts whose demographics favor Democrats, greatly improving their chances of success. Therefore our findings are consistent with previous research (Haider- 
Markel 2010) and do not suggest that the Trump era has changed the dynamic for LGBT candidates.

Even though Democratic LGBTQ candidates are often successful, few LGBTQ candidates have devised a formula for running successful campaigns as Republicans in Republican-leaning districts. As public attitudes towards LGBTQ candidates continue to improve, we might begin to see more LGBTQ Republicans devise a winning formula.

Finally, our results are preliminary and rely on an incomplete dataset. We are still filling some gaps on election outcomes and the percentage of the vote received by candidates. Additionally, there are supplementary ways in which we can analyze our data to tease out a number of conditional or interacting characteristics. However, we are confident that the results of our fuller analysis will not differ dramatically from those presented here. 


\section{References}

Caron, Christina. 2018. “In 'Rainbow Wave,' L.G.B.T. Candidates Are Elected in Record Numbers," The New York Times, November 7. Accessed: https://www.nytimes.com/2018/11/07/us/politics/lgbt-election-winners$\underline{\text { midterms.html }}$

Casey, Logan, and Andrew Reynolds. 2015. Standing Out: Transgender and Gender Variant Candidates and Elected Officials Around the World. Chapel Hill, NC: LGBTQ Representation and Rights. Accessed:

https://docs.wixstatic.com/ugd/6ca1ca cea3d9d601624569b3dc89b90feb9674.pdf

Castle, Jeremiah, 2018. "New Fronts in the Culture Wars? Religion, Partisanship, and Polarization on Religious Liberty and Transgender Rights in the United States." American Politics Research. https://doi.org/10.1177/1532673X18818169

Chenoweth, Erica and Jeremy Pressman. 2017. "This is what we learned by counting the women's marches," The Monkey Cage: The Washington Post, February 7. Accessed: https://www.washingtonpost.com/news/monkey-cage/wp/2017/02/07/this-is-whatwe-learned-by-counting-the-womens-marches/?utm term=.ede5311c132c

Darby, Luke. 2018. "Danica Roem Talks Serving Under Trump, Thrash Metal, and How to Win Local Elections." GQ. January 8, Accessed: https://www.gq.com/story/danica-roem$\underline{\text { how-to-win-elections-interview }}$

Flores, Andrew, Donald Haider-Markel, Daniel Lewis, Patrick Miller, Barry Tadlock, and Jami Taylor. 2018a. “Challenged Expectations: Mere Exposure Effects on Attitudes about Transgender People and Rights." Political Psychology 39(1): 197-216. 
Flores, Andrew, Donald Haider-Markel, Daniel Lewis, Patrick Miller, Barry Tadlock, and Jami Taylor. 2018b. “Transgender Prejudice Reduction and Opinions on Transgender Rights: Results from a Mediation Analysis on Experimental Data." Research \& Politics, doi: 10.1177/2053168018764945..

Gabbatt, Adam. 2017. "The Resistance Now: transgender candidate beats Virginia's 'chief Homophobe.'" The Guardian. November 11, Accessed: https://www.theguardian.com/us-news/2017/nov/11/democrat-election-victories$\underline{\text { danica-roem-ravinder-bhalla-wilmot-collins }}$

Gates, Gary. 2011. "How Many People Are Lesbian, Gay, Bisexual, and Transgender?" The Williams Institute. Accessed June 7, 2017 from https://williamsinstitute.law.ucla.edu/wp-content/uploads/Gates-How-Many-PeopleLGBT-Apr-2011.pdf

Golebiowska, Ewa A. "Group stereotypes and political evaluation." American Politics Research 29, no. 6 (2001): 535-565.

Haider-Markel, Donald P. 2010. Out and Running: Gay and Lesbian Candidates, Elections, and Policy Representation. Washington, DC: Georgetown University Press.

Haider-Markel, Donald P., and Patrick Gauding. 2019. "LGBT Judges in the U.S." In Race, Gender, Sexuality, and the Judiciary, eds. Samantha Hernandez and Sharon A. Navarro. Cambridge: Cambridge University Press. Pp. 77-97.

Haider-Markel, Donald P., Patrick R. Miller, Andrew Flores, Daniel Lewis, Barry Tadlock, and Jami Taylor. 2017. “Bringing ' $T$ ' to the Table: Understanding Individual Support of Transgender Candidates for Public Office." Politics, Groups, and Identities 5(3): 399-417. 
Harrison, Brian and Melissa Michelson. 2017. Listen, We Need to Talk: How to Change Attitudes about LGBT Rights. New York: Oxford University Press.

Herrick, Rebekah, and Sue Thomas. 1999. "The Effects of Sexual Orientation on Citizen Perceptions of Candidate Viability." In Gays and Lesbians in the Democratic Process, Eds. Ellen D. B. Riggle and Barry Tadlock. New York: Columbia University Press.

Hogan, Robert E. 2008. Policy Responsiveness and Incumbent Reelection in State Legislatures." American Journal of Political Science 52(4):858-73.

Jones, Philip Edward, Paul R. Brewer, Dannagal G. Young, Jennifer L. Lambe, and Lindsay H. Hoffman. 2018. “Explaining Public Opinion toward Transgender People, Rights, and Candidates." Public Opinion Quarterly 82(2): 252-278.

Lavers, Michael K. 2017. "Danica Roem campaign reports anti-transgender robocalls," The Washington Blade, October 10. Accessed: https://www.washingtonblade.com/2017/10/10/danica-roem-campaign-reports-antitransgender-robocalls/

Lewis, Daniel, Andrew Flores, Donald Haider-Markel, Patrick Miller, Barry Tadlock, and Jami Taylor. 2017. "Degrees of Acceptance: Variation in Public Attitudes toward Segments of the LGBT Community." Political Research Quarterly 70(4): 861-875.

Magni, Gabriele, and Andrew Reynolds. 2018. "Candidate Sexual Orientation Didn't Matter (in the Way You Might Think) in the 2015 UK General Election." American Political Science Review 112(3): 713-720. 
Miller, Patrick, Andrew Flores, Donald Haider-Markel, Daniel Lewis, Barry Tadlock, and Jami Taylor. 2017. "Transgender Politics as Body Politics: Effects of Disgust Sensitivity and Authoritarianism on Transgender Rights Attitudes." Politics, Groups, and Identities 5(1): 4-24.

Olivo, Antonio. 2017a. “Danica Roem of Virginia to be first openly transgender person elected, seated in a U.S. statehouse," The Washington Post. November 8, Accessed: https://www.washingtonpost.com/local/virginia-politics/danica-roem-will-be-vas-firstopenly-transgender-elected-official-after-unseating-conservative-robert-g-marshall-inhouse-race/2017/11/07/d534bdde-c0af-11e7-959c$\underline{\text { fe2b598d8c00 story.html?utm term=.16ae7e52541f }}$

Olivo, Antonio. 2017b. "Who is Danica Roem?" The Washington Post. November 8, Accessed: https://www.washingtonpost.com/local/virginia-politics/meet-danica-roem-virginiasfirst-transgender-elected-official/2017/11/08/18bd9250-c444-11e7-aae0cb18a8c29c65 story.html?utm term=.14709d42484e

Rayside, David Morton. 1998. On the Fringe: Gays and Lesbians in Politics. Ithaca, NY: Cornell University Press.

Reynolds, Andrew. 2018. The Children of Harvey Milk: How LGBTQ Politicians Changed the World. New York: Oxford University Press.

Smith, Raymond A., and Donald P. Haider-Markel. 2002. Gay and Lesbian Americans and Political Participation. Denver: ABC-CLIO Publishers

Stack, Liam. 2018. "Facing Threats and Bias, L.G.B.T. Candidates Are Running in Record Numbers," The New York Times, November 5. Accessed: 
https://www.nytimes.com/2018/11/05/us/politics/lgbt-candidates.html?module=inline

Sullivan, Patricia. 2017. "Marshall ad accuses Roem of 'lewd behavior' in old video of her band," The Washington Post, October 25. Accessed:

https://www.washingtonpost.com/local/virginia-politics/marshall-ad-accuses-roem-oflewd-behavior-based-on-old-video-of-her-band/2017/10/25/ca12f208-b9a8-11e7-9e58e6288544af98 story.html?utm term=.1877f8e 55730

Taylor, Jami Kathleen, Daniel C. Lewis, and Donald P. Haider-Markel. 2018. The Remarkable Rise of Transgender Rights. Ann Arbor: University of Michigan Press.

Taylor, Jami K., Donald P. Haider-Markel, and Daniel C. Lewis 2018. “Tensions over Gay and Transgender Rights between Localities and States" PS: Political Science and Politics 51(1): 35-37.

Taylor, Jami Kathleen, and Donald P. Haider-Markel. Eds. 2014. Transgender Rights and Politics: Groups, Issue Framing, and Policy Adoption. Ann Arbor: University of Michigan Press.

Zhou, Li. 2019. "A Historic New Congress will be sworn in today," Vox, January 3. Accessed: https://www.vox.com/2018/12/6/18119733/congress-diversity-women-election-goodnews 


\section{Out LGBT US State House Members}

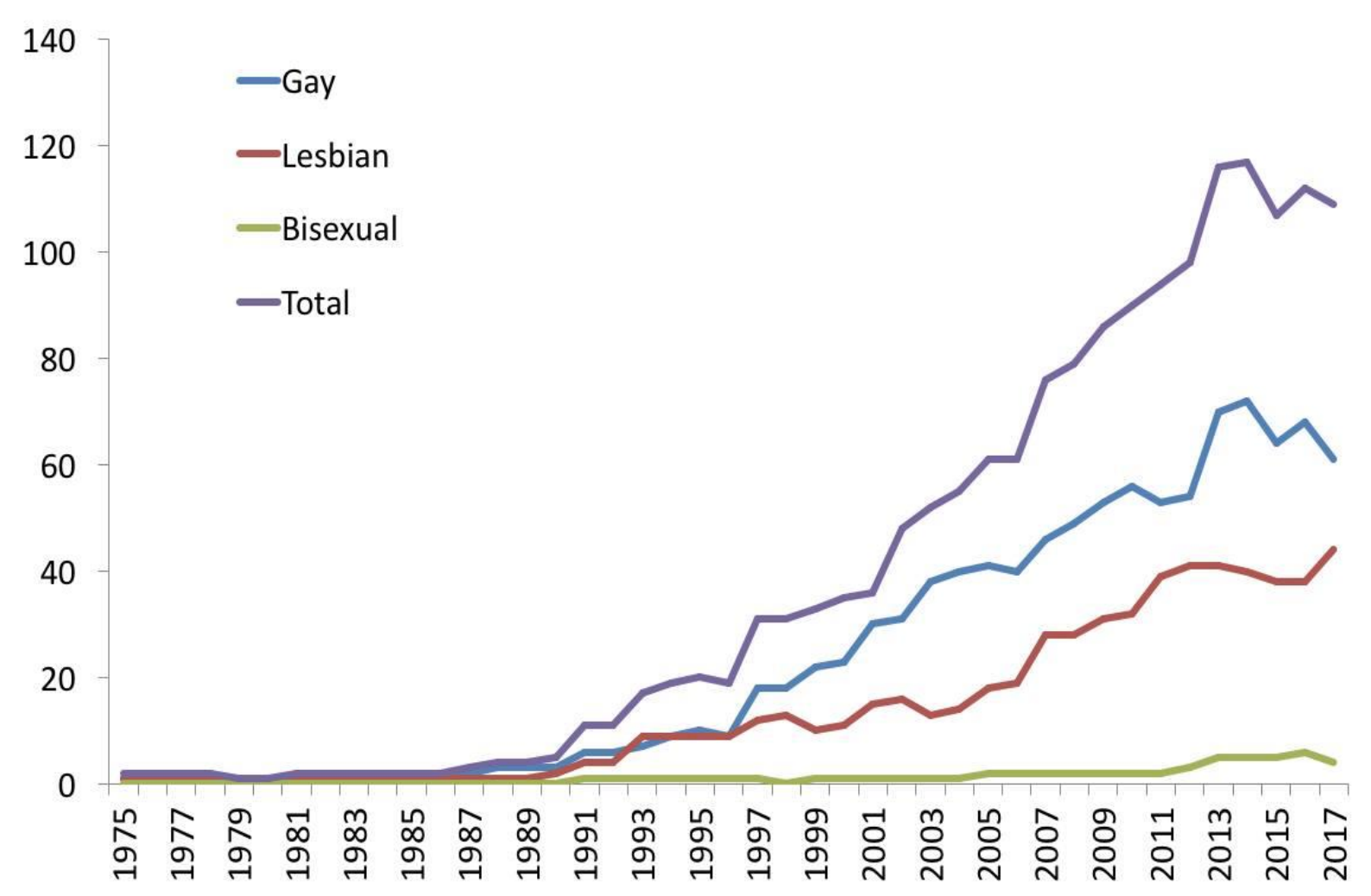

Source: Charles W. Gossett and the UNC LGBTQ Representation and Rights Research Initiative 
Table 1: Likelihood that State Legislative Candidate will Win General Election, By Party, 2018

\begin{tabular}{|c|c|}
\hline $\begin{array}{l}\text { Independent } \\
\text { Variables }\end{array}$ & $\begin{array}{l}\text { Democratic } \\
\text { Candidate }\end{array}$ \\
\hline LGBT Candidate & $\begin{array}{l}-.037 \\
(.226)\end{array}$ \\
\hline Less Experience & $\begin{array}{l}-.245^{* *} \\
(.029)\end{array}$ \\
\hline Gender ^^Female & $\begin{array}{c}.038 \\
(.048)\end{array}$ \\
\hline Upper Chamber Race & $\begin{array}{l}.059 \\
(.062)\end{array}$ \\
\hline$\%$ Urban & $\begin{array}{l}-.001 \\
(.001)\end{array}$ \\
\hline \% Democrat, lag & $\begin{array}{l}.044 * * \\
(.001)\end{array}$ \\
\hline$\%$ College Educated & $\begin{array}{l}.040 * * \\
(.004)\end{array}$ \\
\hline$\%$ African-American & $\begin{array}{l}.059 * * \\
(.004)\end{array}$ \\
\hline \% Hispanic & $\begin{array}{l}.026^{* *} \\
(.003)\end{array}$ \\
\hline Same-Sex Households & $\begin{array}{l}.392^{* *} \\
(.104)\end{array}$ \\
\hline$\%$ Protestant Fundamentalist & missing \\
\hline Constant & $\begin{array}{l}2.674^{* *} \\
(.138)\end{array}$ \\
\hline Log Likelihood & -4598.964 \\
\hline Peusdo R-squared & .32 \\
\hline LR Chi-Square & 4309.66 \\
\hline Prob. Chi-Square & .000 \\
\hline Number of Cases & 9848 \\
\hline
\end{tabular}

Notes: Coefficients are Logistic regression coefficients. Standard errors are in parenthesis.

Significance levels: $* *<.01 ; *<.05$. 